\title{
Determinant Factors Affecting Intention of Child Marriage to Adolescents in Banggai Laut
}

\author{
Nur Indri Wahyuni ${ }^{1}$, Apik Indarty Moedjiono ${ }^{1}$, Muhammad Tamar ${ }^{2}$ \\ indienon1994@gmail.com \\ ${ }^{1}$ Department of Reproductive Health, Faculty of Public Health, Hasanuddin University, \\ Indonesia \\ ${ }^{2}$ Department of Psychology, Faculty of Medicine, Hasanuddin University, Indonesia \\ Received: Desembr 29, 2020 \\ Received in revised: January 14, 2021 \\ Accepted: January 27, 2021
}

\begin{abstract}
This study aims to look at the determinant factors that affect the intense / intention to do child marriage to adolescents in Banggai Laut. This research method using a cross sectional study. The research sample consisted of 192 teenage students in SMA Negeri 1 Banggai and SMA Negeri 2 Banggai. Chi-square test and multiple logistic regression were used to analyze the data. The results of the bivariate analysis showed that there was an effect of attitude, family drive and behavior control on the intention to do child marriage $(\mathrm{p}<0.05)$. The results of the multivariate analysis showed that there was only one variable that had a $\mathrm{p}$ value $<0.05$, namely the family drive variable with $\mathrm{p}=0.029$. From $\exp (\mathrm{B})=4,871>1$ is a risk factor and the $\mathrm{Cl}$ value is $95 \%$ more than $1(1,178-20,142)$ so that OR is significant. This means that respondents who are influenced by family encouragement have a risk of 4,871 times having the intention of engaging in child marriage. It can be concluded that there are many factors that can influence adolescents in engaging in child marriage. All levels of society should protect children together and stop the practice of child marriage in society. The smallest and closest family unit for the child should be able to protect it, not be the main factor that encourages underage marriage.
\end{abstract}

Keywords: Child Marriage, Planned Behavior, Determinant Factor

\section{Introduction}

Child marriage is a multi-dimensional problem. Some of them are closely related to community customs and traditions, the economy, access to health information, access to education services, relationships at risk, and so on. Child marriage is identified as one of the social phenomena that causes major problems in the country, including poverty, high maternal mortality (MMR), infant mortality (AKBI), low APS (School Participation Rate), high unemployment rates and others.

Various facts show that girls who marry young face adverse consequences to their health as a result of childbirth at an immature age, an increased risk of domestic violence, malnutrition, and sexual and reproductive health problems (Ame, 2013; Parsons et al., 2015; Marphatia et al., 2017). They suffer worse from all social and economic indicators than girls who delay marriage, including lower levels of education and higher levels of poverty. This bad impact will also be experienced by their children and can continue for future generations (ICJ, 2019; GonzalezRicoy \& Rey, 2019). 
According to the United Nations Development Economic and Social Affairs, Indonesia is the 37 th country with a high percentage of young marriages and is the second highest in ASEAN after Cambodia, a source from UNDESA 2010 in the Ministry of Health 2015 (Infodatin, 2015). First Marriage Age under 15 years, 2016-2018 that Central Sulawesi ranks third in 2016 with $8.10 \%$, in 2017 it decreased to fourth position with a percentage of $7.89 \%$ and in 2018 it decreased to fifth position with a total percentage of $7,03 \%$ with a marriage rate under 15 years.

The Office of Religious Affairs of Banggai, Banggai Laut Regency, stated that in 2017 the number of marriages under the age of 19 was 59 for women and 1 person for male cases. In 2019, there were 50 cases of marriage under the age of 19 for women and 3 cases for men.

Ajzen (1980) argues that the intention to do or not do certain behaviors is influenced by two basic determinants, the first is related to attitude (attitude towards behavior) and the other is related to social influence, namely subjective norms. Therefore, the authors are interested in conducting research in Banggai Laut on students of SMA Negeri 1 Banggai and SMA Negeri 2 Banggaidi Banggai Laut, with the title "Determinant Factors that Influence Intention to Conduct Child Marriage in Adolescents in Banggai Laut, 2020"

\section{Methods}

This type of research is a quantitative study with a cross sectional study design. The population in this study were 384 grade XI students of SMA Negeri 1 Banggai and SMA Negeri 2 Banggai in Banggai Laut in 2020. The sample size in this study was 192 adolescents. This research was conducted at SMA Negeri 1 Banggai and SMA Negeri 2 Banggai.

All data collected is recorded in a special form or indole table and processed using statistics in accordance with the measurement scale and research objectives. The entire data collected is then verified and completed according to the actual situation.

The process of analyzing data data is carried out using certain statistical software which begins with the process of checking the normality of the distribution of the data tested using statistical tests. The basis for decision making is based on probability. If the probability> 0.05 then Ho is rejected, this means that the two variables have no effect. However, if Ho is accepted, this means that the two variables have an influence. In addition, multivariate analysis is an analysis to test the effect of independent variables with the dependent variable collectively using multiple logistic regression analysis, with a significance level of $\mathrm{p}<0.025$.

\section{Results and Discussion}

Table 1.Distribution of Respondents Based on Respondent Characteristics of Students at SMA Negeri 1 Banggai and SMA Negeri 2 Banggai in 2020

\begin{tabular}{|l|c|c|}
\hline Respondent Charakteristic & Amount (n) & Percentage (\%) \\
\hline a. Sex & & \\
Male & 64 & 33.3 \\
Female Total & 128 & 66.7 \\
\hline \multicolumn{1}{|c|}{ (192 } & $\mathbf{1 0 0 . 0}$ \\
\hline b. Age & & \\
15 years & 41 & 21.4 \\
16 years & 147 & 76.6 \\
$\geq 17$ years & 4 & 2.1 \\
\hline
\end{tabular}




\begin{tabular}{|l|c|c|}
\hline \multicolumn{1}{|c|}{ Total } & $\mathbf{1 9 2}$ & $\mathbf{1 0 0 . 0}$ \\
\hline c. Father's Last Education & 2 & \\
Elementary School & 4 & 1.0 \\
Junior School & 91 & 2.1 \\
High School & 95 & 47.4 \\
Higher Education & $\mathbf{1 9 2}$ & 49.5 \\
\hline \multicolumn{1}{|c|}{ Total } & & \\
\hline d. Mother's Last Education & 8 & 4.2 \\
Elementary School & 10 & 5.2 \\
Junior School & 100 & 52.1 \\
High School & 74 & 38.5 \\
\hline Higher Education & $\mathbf{1 9 2}$ & $\mathbf{1 0 0 . 0}$ \\
\hline \multicolumn{1}{|c|}{ Total } &
\end{tabular}

Source: Primary Data 2020

Table 1 shows that based on gender, the number of female respondents is more (66.7\%). Based on age, more respondents aged 16 years $(76.6 \%)$. Based on the education of their parents, the number of fathers who continued their education to tertiary education was more (49.5\%). Based on maternal education, more high school graduates (52.1\%).

Table 2.Frequency Distribution of Respondents Based on Research Variables on Marriage under the Age of Marriage in 2020

\begin{tabular}{|c|c|c|}
\hline Research Variable & Amount (n) & Percentage $(\%)$ \\
\hline $\begin{array}{ll}\text { a. } & \text { Intention } \\
\text { Intending } \\
\text { Not Intending }\end{array}$ & $\begin{array}{l}95 \\
97\end{array}$ & $\begin{array}{l}49.5 \\
50.5\end{array}$ \\
\hline Total & 192 & 100.0 \\
\hline $\begin{array}{l}\text { b. Attitude } \\
\text { Positive } \\
\text { Negative }\end{array}$ & $\begin{array}{c}110 \\
82\end{array}$ & $\begin{array}{l}57.3 \\
42.7\end{array}$ \\
\hline Total & 192 & 100.0 \\
\hline $\begin{array}{l}\text { c. Family Support } \\
\text { Small Support } \\
\text { Big Support }\end{array}$ & $\begin{array}{l}98 \\
94\end{array}$ & $\begin{array}{l}51.0 \\
49.0\end{array}$ \\
\hline Total & 192 & 100.0 \\
\hline $\begin{array}{l}\text { d. } \text { Peer Role } \\
\text { Play a small role } \\
\text { Play a big role }\end{array}$ & $\begin{array}{c}92 \\
100\end{array}$ & $\begin{array}{l}47.9 \\
52.1\end{array}$ \\
\hline Total & 192 & 100.0 \\
\hline $\begin{array}{l}\text { e. Effects of Living Environment } \\
\text { Small Effect } \\
\text { Big Effect }\end{array}$ & $\begin{array}{l}95 \\
97\end{array}$ & $\begin{array}{l}49.5 \\
50.5\end{array}$ \\
\hline Total & 192 & 100.0 \\
\hline $\begin{array}{l}\text { f. Effects of School Environment } \\
\text { Small Effect } \\
\text { Big Effect }\end{array}$ & $\begin{array}{c}81 \\
111 \\
\end{array}$ & $\begin{array}{l}42.2 \\
57.8 \\
\end{array}$ \\
\hline
\end{tabular}




\begin{tabular}{|l|c|c|}
\hline \multicolumn{1}{|c|}{ Total } & $\mathbf{1 9 2}$ & $\mathbf{1 0 0 . 0}$ \\
\hline $\begin{array}{l}\text { g. } \text { Effects of public Figure } \\
\text { Small Effect }\end{array}$ & 82 & \\
Big Effect & 110 & 42.7 \\
\hline \multicolumn{1}{|c|}{ Total } & $\mathbf{1 9 2}$ & 57.3 \\
\hline h. Attitude Control & & $\mathbf{1 0 0 . 0}$ \\
No Support & 77 & 40.1 \\
There is Support & 115 & 59.9 \\
\hline \multicolumn{1}{|c|}{ Total } & $\mathbf{1 9 2}$ & $\mathbf{1 0 0 . 0}$ \\
\hline
\end{tabular}

Source: Primary Data 2020

Table 2 shows based on the intention, respondents who intend more (50.5\%). Based on the attitude variable, there were more respondents with positive attitudes (57.3\%). Based on the family motivation variable, more respondents had little motivation (51.0\%). Based on the behavioral control variable, more respondents have encouragement (59.9\%)

Table 3. The Effect of Attitudes on Intention of Marriage Under the Age of Marriage by Age

\begin{tabular}{|c|c|c|c|c|c|c|}
\hline \multirow{3}{*}{ Age } & \multirow{3}{*}{ Attitude } & \multicolumn{4}{|c|}{ Intention } & \multirow{2}{*}{ P } \\
\cline { 3 - 6 } & & \multicolumn{2}{|c|}{ Not Intending } & \multicolumn{2}{|c|}{ Intending } & \\
\cline { 3 - 6 } & n & $\%$ & $\mathrm{n}$ & $\%$ & \\
\hline \multirow{3}{*}{$>$ mean } & Positive & 41 & 48.2 & 44 & 51.8 & \multirow{3}{*}{0.369} \\
\cline { 2 - 6 } & Negative & 27 & 40.9 & 39 & 59.1 & \\
\cline { 2 - 6 } & Total & 68 & 45.0 & 83 & 55.0 & \\
\hline \multirow{3}{*}{$\leq$ mean } & Positive & 13 & 52.0 & 12 & 48.0 & \multirow{3}{*}{0.019} \\
\cline { 2 - 6 } & Negative & 14 & 87.5 & 2 & 12.5 & \\
\cline { 2 - 5 } & Total & 27 & 65.9 & 14 & 34.1 & \\
\hline
\end{tabular}

Source: Primary Data 2020

Table 3 shows that based on age above the mean there are more respondents with negative attitudes (59.1). Based on the age below the mean there were more respondents with a positive attitude (48.0\%). The results of the analysis showed that there was an influence of attitude on the intention to do child marriage based on age below the mean for Banggai Laut adolescents ( $p$ $<0.05)$.

Table 4. The Effect of Attitudes on Intention to Marriage Under the Age of Marriage Under the Age of Marriage based on gender

\begin{tabular}{|c|c|c|c|c|c|c|}
\hline \multirow{3}{*}{ Sex } & \multirow{3}{*}{ Attitude } & \multicolumn{4}{|c|}{ Intention } & \multirow{3}{*}{$\mathbf{P}$} \\
\hline & & \multicolumn{2}{|c|}{ Not Intending } & \multicolumn{2}{|c|}{ Intending } & \\
\hline & & $\mathrm{n}$ & $\%$ & $\mathrm{n}$ & $\%$ & \\
\hline \multirow{3}{*}{ Male } & Positive & 40 & 57.1 & 30 & 42.9 & \multirow{3}{*}{0.675} \\
\hline & Negative & 31 & 53.4 & 27 & 46.6 & \\
\hline & Total & 71 & 55.5 & 57 & 44.5 & \\
\hline \multirow{4}{*}{ Female } & Positive & 14 & 35.0 & 26 & 65.0 & \multirow{4}{*}{0.594} \\
\hline & Negative & 10 & 41.7 & 14 & 58.3 & \\
\hline & Total & 24 & 37.5 & 40 & 62.5 & \\
\hline & Negative & 41 & 50.0 & 41 & 50.0 & \\
\hline
\end{tabular}


Source: Primary Data 2020

Table 4 shows that there were more male respondents with negative attitudes (46.6\%). Based on female gender, there were more respondents with positive attitudes $(65.0 \%)$. The results of the analysis showed that there was no effect of attitude on the intention to do child marriage based on gender in Banggai Laut adolescents ( $p>0.05$ ).

Table 5. The Effect of Attitudes on Intention of Conducting Marriage Under the Age of Marriage based on Father's Education

\begin{tabular}{|c|c|c|c|c|c|c|}
\hline \multirow{3}{*}{$\begin{array}{c}\text { Father's } \\
\text { education }\end{array}$} & \multirow{2}{*}{ Attitude } & \multicolumn{4}{|c|}{ Intention } & \multirow{2}{*}{ P } \\
\cline { 3 - 6 } & & Not Intending & \multicolumn{2}{|c|}{ Intending } & \\
\cline { 2 - 6 } & Lositive & 0 & $\%$ & $\mathrm{n}$ & $\%$ & \\
\cline { 2 - 6 } Low & Negative & 0 & 0.0 & 6 & 100 & \multirow{3}{*}{-} \\
\cline { 2 - 6 } & Total & 0 & 0.0 & 6 & 100 & \\
\hline \multirow{3}{*}{ Enough } & Positive & 54 & 51.9 & 50 & 48.1 & \multirow{3}{*}{0.749} \\
\cline { 2 - 6 } & Negative & 41 & 50.0 & 41 & 50.0 & \\
\cline { 2 - 5 } & Total & 95 & 51.1 & 91 & 48.9 & \\
\hline
\end{tabular}

Source: Primary Data 2020

Table 5 shows the analysis of the influence of attitudes on the intention to marry children based on low father's education cannot be done because the attitude value is constant. Based on the father's education, there were more respondents with negative attitudes (50.0\%). The results of the analysis showed that there was no effect on the attitude towards the intention of child marriage based on the father's education for Banggai Laut adolescents ( $p>0.05$ ).

Table 6. The Effect of Attitudes on Intention of Conducting Marriage Under the Age of Marriage based on Mother's Education

\begin{tabular}{|c|c|c|c|c|c|c|}
\hline \multirow{2}{*}{$\begin{array}{c}\text { Mother's } \\
\text { education }\end{array}$} & \multirow{2}{*}{ attitude } & \multicolumn{4}{|c|}{ Intention } & \multirow{2}{*}{ P } \\
\cline { 3 - 7 } & & \multicolumn{2}{|c|}{ Not Intending } & \multicolumn{2}{|c|}{ Intending } & \\
\cline { 3 - 6 } & Positive & 4 & 28.6 & 10 & 71.4 & \\
\hline \multirow{3}{*}{ Low } & Negative & 3 & 75.0 & 1 & 25.0 & \multirow{2}{*}{0.093} \\
\cline { 2 - 6 } & Total & 7 & 38.9 & 11 & 61.1 & \\
\hline \multirow{3}{*}{ Enough } & Positive & 50 & 52.1 & 46 & 47.9 & \multirow{3}{*}{0.659} \\
\cline { 2 - 6 } & negative & 38 & 48.7 & 40 & 51.3 & \\
\cline { 2 - 6 } & Total & 88 & 50.6 & 86 & 49.4 & \\
\hline
\end{tabular}

Source: Primary Data 2020

Table 6 shows that based on low maternal education, there were more respondents with a positive attitude $(71.4 \%)$. Based on sufficient maternal education, more respondents with negative attitudes (51.3\%). The results of the analysis showed that there was no effect on attitudes towards the intention of having child marriage based on the mother's education for Banggai Laut adolescents ( $p>0.05$ ). 
Table 7. The Influence of Family Encouragement on Intention to Marriage Under the Age of Marriage based on age

\begin{tabular}{|c|c|c|c|c|c|c|}
\hline \multirow{3}{*}{$\begin{array}{l}\text { Mother's } \\
\text { education }\end{array}$} & \multirow{3}{*}{$\begin{array}{c}\text { Family } \\
\text { Support }\end{array}$} & \multicolumn{4}{|c|}{ Intention } & \multirow{3}{*}{$\mathbf{P}$} \\
\hline & & \multicolumn{2}{|c|}{ Not Intending } & \multicolumn{2}{|c|}{ Intending } & \\
\hline & & $\mathrm{n}$ & $\%$ & $\mathrm{n}$ & $\%$ & \\
\hline \multirow{3}{*}{ >mean } & Positive & 35 & 46.1 & 41 & 53.9 & \multirow{3}{*}{0.800} \\
\hline & Negative & 33 & 44.0 & 42 & 56.0 & \\
\hline & Total & 68 & 450 & 83 & 55.0 & \\
\hline \multirow{3}{*}{$\leq$ mean } & Positive & 16 & 72.7 & 6 & 27.3 & \multirow{3}{*}{0.318} \\
\hline & negative & 11 & 57.9 & 8 & 42.1 & \\
\hline & Total & 27 & 50.6 & 14 & 49.4 & \\
\hline
\end{tabular}

Source: Primary Data 2020

Table 7 shows that based on age above the mean more respondents with negative family encouragement $(56.0 \%)$. Based on the age below the mean more respondents with negative family encouragement $(42.1 \%)$. The result of the analysis shows that there is no influence of family motivation on the intention to marry children based on age in Banggai Laut adolescents ( $\mathrm{p}>0.05)$.

\section{Table 8. The Effect of Family Encouragement on Intention to Marriage Under the Age of} Marriage based on gender

\begin{tabular}{|c|c|c|c|c|c|c|}
\hline \multirow{3}{*}{ Sex } & \multirow{3}{*}{ Family Support } & \multicolumn{4}{|c|}{ Intention } & \multirow{3}{*}{$\mathrm{P}$} \\
\hline & & \multicolumn{2}{|c|}{ Not Intending } & \multicolumn{2}{|c|}{ Intending } & \\
\hline & & $\mathrm{n}$ & $\%$ & $\mathrm{n}$ & $\%$ & \\
\hline \multirow{3}{*}{ Male } & Small Support & 37 & 51.4 & 35 & 48.6 & \multirow{3}{*}{0.292} \\
\hline & Big Support & 34 & 60.7 & 22 & 39.3 & \\
\hline & Total & 71 & 55.5 & 57 & 44.5 & \\
\hline \multirow{3}{*}{ Female } & Small Support & 14 & 53.8 & 12 & 46.2 & \multirow{3}{*}{0.025} \\
\hline & Big Support & 10 & 26.3 & 28 & 73.7 & \\
\hline & Total & 24 & 37.5 & 40 & 62.5 & \\
\hline
\end{tabular}

Source: Primary Data 2020

Table 8 shows that male sex is more prevalent in the family drive (48.6\%). Based on the sex of women more on family encouragement $(73.7 \%)$. The results of the analysis showed that there was an effect of family motivation on the intention of having child marriage based on the gender of the Banggai Laut adolescent ( $\mathrm{p}<0.05)$.

Table 9. The Effect of Family Encouragement on Intention to Marriage Under the Age of Marriage based on the father's education

\begin{tabular}{|c|c|c|c|c|c|c|}
\hline \multirow{2}{*}{$\begin{array}{c}\text { Father's } \\
\text { Education }\end{array}$} & \multirow{2}{*}{ Family Support } & \multicolumn{4}{|c|}{ Intention } & \multirow{2}{*}{ P } \\
\cline { 3 - 6 } & & \multicolumn{2}{|c|}{ Not Intending } & \multicolumn{2}{|c|}{ Intending } & \\
\cline { 3 - 6 } & & $\mathrm{n}$ & $\%$ & $\mathrm{n}$ & $\%$ & \\
\hline \multirow{2}{*}{ Low } & Small Support & 35 & 46.1 & 41 & 53.9 & 0.800 \\
& Big Support & 33 & 44.0 & 42 & 56.0 & \\
\cline { 2 - 6 } & Total & 68 & 45.0 & 83 & 55.0 & \\
\cline { 2 - 6 } & Small Support & 16 & 72.7 & 6 & 27.3 & 0.318 \\
\hline \multirow{2}{*}{ Enough } & Smal & \multicolumn{4}{|c}{} & \\
\hline
\end{tabular}




\begin{tabular}{|l|c|c|c|c|c|c|}
\hline & Big Support & 11 & 57.9 & 18 & 42.1 & \\
\cline { 2 - 6 } & Total & 27 & 69.9 & 14 & 34.1 & \\
\hline
\end{tabular}

Source: Primary Data 2020

Table 9 shows that based on lower father's education, it is greater for respondents with a large family drive $(56.0 \%)$. Based on the father's education, it is quite high for respondents with a large family drive (42.1\%). The results of the analysis show that there is no effect of family motivation on the intention to do child marriage based on the father's education for Banggai Laut adolescents ( $\mathrm{p}>0.05)$.

Table 10. The Effect of Family Encouragement on Intention to Marriage under the Age of Marriage based on the mother's education

\begin{tabular}{|c|c|c|c|c|c|c|}
\hline \multirow{2}{*}{$\begin{array}{c}\text { Mother's } \\
\text { education }\end{array}$} & \multirow{2}{*}{ Family Support } & \multicolumn{4}{|c|}{ Intention } & \multirow{2}{*}{ P } \\
\cline { 3 - 6 } & & \multicolumn{2}{|c|}{ Not Intending } & \multicolumn{2}{|c|}{ Intending } & \multirow{2}{*}{0} \\
\cline { 2 - 6 } & Small Support & 0 & 0.0 & 9 & 100 & \multirow{3}{*}{0.001} \\
\hline \multirow{3}{*}{ Low } & Big Support & 7 & 77.8 & 2 & 22.2 & \\
\cline { 2 - 6 } & Total & 7 & 38.9 & 11 & 61.1 & \\
\hline \multirow{3}{*}{ Enough } & Small Support & 51 & 57.3 & 38 & 42.7 & \multirow{3}{*}{0.069} \\
\cline { 2 - 6 } & Big Support & 37 & 43.5 & 48 & 56.5 & \\
\cline { 2 - 6 } & Total & 88 & 50.6 & 86 & 49.4 & \\
\hline
\end{tabular}

Source: Primary Data 2020

Table 10 shows that based on lower maternal education, it is greater for respondents with little family drive (100\%). Based on maternal education, it is quite high for respondents with a large family encouragement (56.5\%). The results of the analysis show that there is an effect of family motivation on the intention to do child marriage based on low maternal education for Banggai Laut adolescents $(\mathrm{p}<0.05)$.

Table 11. The Effect of Behavior Control on Intention to Conduct Marriage under the Age of Marriage based on age

\begin{tabular}{|c|c|c|c|c|c|c|}
\hline \multirow{3}{*}{ Age } & \multirow{3}{*}{ Attitude Control } & \multicolumn{4}{|c|}{ Intention } & \multirow{3}{*}{$\mathbf{P}$} \\
\hline & & \multicolumn{2}{|c|}{ Not Intending } & \multicolumn{2}{|c|}{ Intending } & \\
\hline & & $\mathrm{n}$ & $\%$ & $\mathrm{n}$ & $\%$ & \\
\hline \multirow{3}{*}{ >mean } & Small Effect & 53 & 100 & 0 & 0.0 & \multirow{3}{*}{0.000} \\
\hline & Big Effect & 15 & 17.6 & 83 & 82.4 & \\
\hline & Total & 68 & 45.0 & 83 & 55.0 & \\
\hline \multirow{3}{*}{$\leq$ mean } & Small Effect & 24 & 100 & 0 & 0.0 & \multirow{3}{*}{0.000} \\
\hline & Big Effect & 3 & 17.6 & 14 & 82.4 & \\
\hline & Total & 27 & 65.9 & 14 & 34.1 & \\
\hline
\end{tabular}

Source: Primary Data 2020

Table 11 shows that based on age above the mean there are more respondents with a large influence behavior control (82.4\%). Based on the age below the mean, there were more respondents with a large influence behavior control $(82.4 \%)$. The results of the analysis showed that there was an effect of behavioral control on the intention to marry children based on age in Banggai Laut adolescents ( $\mathrm{p}<0.05)$. 
Table 12. The Effect of Behavior Control on Intention to Conduct Marriage Under the Age of Marriage based on gender

\begin{tabular}{|c|c|c|c|c|c|c|}
\hline \multirow{3}{*}{ Sex } & \multirow{2}{*}{ Attitude Control } & \multicolumn{4}{|c|}{ Intention } & \multirow{2}{*}{ P } \\
\cline { 3 - 6 } & & Not Intending & \multicolumn{2}{|c|}{ Intending } & \\
\cline { 2 - 6 } & Small Effect & $\mathrm{n}$ & $\%$ & $\mathrm{n}$ & $\%$ & \\
\hline \multirow{3}{*}{ Male } & Big Effect & 11 & 100 & 0 & 0.0 & \multirow{3}{*}{0.000} \\
\cline { 2 - 6 } & Total & 71 & 55.5 & 57 & 44.5 & \\
\cline { 2 - 6 } Female & Small Effect & 17 & 100 & 0 & 0.0 & \multirow{2}{*}{0.000} \\
\cline { 2 - 6 } & Big Effect & 7 & 14.9 & 40 & 85.1 & \\
\cline { 2 - 6 } & Total & 24 & 37.5 & 40 & 62.5 & \\
\hline
\end{tabular}

Source: Primary Data 2020

Table 12 shows that based on male gender there were more respondents with a large influence behavior control (83.8\%). Based on female gender, there were more respondents with behavioral controls with a large effect $(85.1 \%)$ than those with a small influence behavior control $(0.0 \%)$. The results of the analysis show that there is an effect of behavior control on the intention to do child marriage

Table 13. Effect of Behavioral Control on Intention to Conduct Marriage Under the Age of Marriage based on Father's Education

\begin{tabular}{|c|c|c|c|c|c|c|}
\hline \multirow{2}{*}{$\begin{array}{c}\text { Father's } \\
\text { Education }\end{array}$} & \multirow{2}{*}{ Attitude Control } & \multicolumn{4}{|c|}{ Intention } & \multirow{2}{*}{ P } \\
\cline { 3 - 6 } & & \multicolumn{2}{|c|}{ Not Intending } & \multicolumn{2}{|c|}{ Intending } & \multirow{2}{*}{ - } \\
\cline { 2 - 6 } & Small Effect & 0 & 0.0 & 0 & 0.0 & \\
\hline \multirow{3}{*}{ Low } & Big Effect & 0 & 0.0 & 6 & 100 & \\
\cline { 2 - 6 } & Total & 0 & 0.0 & 6 & 100 & \\
\hline \multirow{3}{*}{ Enough } & Small Effect & 77 & 100 & 0 & 0.0 & \multirow{3}{*}{0.000} \\
\cline { 2 - 6 } & Big Effect & 18 & 16.5 & 91 & 83.5 & \\
\cline { 2 - 6 } & Total & 95 & 51.1 & 91 & 48.9 & \\
\hline
\end{tabular}

Source: Primary Data 2020

Table 13 shows that based on the low father's education, all respondents fall into the category of high influence $(100 \%)$. Based on father's education, there were quite a lot of respondents with a large influence behavior control $(83.5 \%)$. The results of the analysis showed that there was an effect of behavioral control on the intention to do child marriage based on the father's education which was sufficient for Banggai Laut adolescents $(\mathrm{p}<0.05)$.

Table 14. Effect of Behavior Control on Intention / Intention to Conduct Marriage under the Age of Marriage based on Mother's Education

\begin{tabular}{|c|c|c|c|c|c|c|}
\hline \multirow{2}{*}{$\begin{array}{c}\text { Mother's } \\
\text { Education }\end{array}$} & \multirow{2}{*}{ Attitude Control } & \multicolumn{4}{|c|}{ Intention } & \multirow{2}{*}{ P } \\
\cline { 3 - 7 } & & \multicolumn{2}{|c|}{ Not Intending } & \multicolumn{2}{|c|}{ Intending } & \\
\cline { 3 - 7 } & & $\mathrm{n}$ & $\%$ & $\mathrm{n}$ & $\%$ & \\
\hline \multirow{3}{*}{ Rendah } & Small Effect & 4 & 100 & 0 & 0.0 \\
\hline
\end{tabular}




\begin{tabular}{|c|c|c|c|c|c|c|}
\hline \multirow{3}{*}{ Cukup } & Small Effect & 73 & 100 & 0 & 0.0 & \multirow{3}{*}{0.000} \\
\cline { 2 - 7 } & Big Effect & 15 & 14.9 & 86 & 85.1 & \multirow{2}{*}{} \\
\cline { 2 - 7 } & Total & 88 & 50.6 & 86 & 49.4 & \\
\hline
\end{tabular}

Source: Primary Data 2020

Table 14 shows that based on low maternal education, there are more respondents with a large influence behavior control $(100 \%)$. Based on the mother's education, there were quite a lot of respondents with a large influence behavior control (85.1\%). The results of the analysis showed that there was an effect of behavioral control on the intention to do child marriage based on maternal education for Banggai Laut adolescents ( $\mathrm{p}<0.05)$.

Table 15. Results of Multivariate Analysis between Independent Variables on Intention to Marriage Under the Age of Marriage in Banggai Laut Adolescents in 2020

\begin{tabular}{|l|r|r|r|r|r|r|}
\hline \multicolumn{1}{|c|}{ Variable } & \multirow{2}{*}{$\mathbf{B}$} & \multirow{2}{*}{$\mathbf{d f}$} & \multirow{2}{*}{ Exp (B) } & \multirow{2}{*}{$\mathbf{P}$} & \multicolumn{2}{c|}{ 95\% C.I } \\
\cline { 5 - 7 } & & & & & LL & UP \\
\hline Attitude & -.558 & 1 & .572 & .346 & .179 & 1.827 \\
\hline $\begin{array}{l}\text { Family } \\
\text { Encouragement }\end{array}$ & 1.583 & 1 & 4.871 & .029 & 1.178 & 20.142 \\
\hline $\begin{array}{l}\text { Friends of the same } \\
\text { age }\end{array}$ & .814 & 1 & & & & \\
\hline Living environment & .801 & 1 & 2.257 & .366 & .387 & 13.180 \\
\hline School environment & -.708 & 1 & 2.228 & .269 & .538 & 9.234 \\
\hline Public Figure & -.587 & 1 & .493 & .359 & .109 & 2.235 \\
\hline Behavior control & 24.155 & 1 & .556 & .331 & .170 & 1.818 \\
\hline Age & .138 & 1 & 1.147 & .875 & .206 & 6.385 \\
\hline Gender & -.162 & 1 & .850 & .826 & .199 & 3.629 \\
\hline Father's Education & -21.035 & 1 & .000 & .999 & .000 & \\
\hline Education Mother & 1.753 & 1 & 5.770 & .075 & .836 & 39.805 \\
\hline Constant & -9.594 & 1 & .000 & 1.000 & & \\
\hline
\end{tabular}

Source: Primary Data 2020

Table 15 shows the results of multivariate analysis using multiple logistic regression, namely the Enter method. The analysis showed that there was only one variable that had a $\mathrm{p}$ value $<0.05$, namely the family drive variable with $p=0.029$. From $\exp (B)=4,871>1$ is a risk factor and the $\mathrm{Cl}$ value is $95 \%$ more than $1(1,178-20,142)$ so that OR is significant. This means that respondents who are influenced by family encouragement have a risk of 4,871 times having the intention of having child marriage.

The results of the bivariate analysis between attitudes towards the intention of child marriage based on age, gender, father's education and mother's education showed that age was below the mean influence on attitudes towards child marriage among adolescents in Banggai Laut. This shows that the attitude towards child marriage is very influential on the age and maturity level of the child itself. The lower the age, the less knowledgeable about the risks of child marriage.

In Pandey's (2017) study in Nepal, as the education of boys and girls increases, the risk of getting married before the age of 16 decreases significantly. The results of Moedjiono's research (2019) The age at most for the first time having sexual intercourse with male adolescents was at the age of 17, namely 254 people (20.2\%), while the age at first sexual intercourse with adolescents was 
at least 11 years old two people $(0.2 \%)$. This is also explained in the research by Rifai et al (2019) which needs to prioritize women's education in terms of pregnancy and risk knowledge.

Moedjiono's (2020) research explains that there is also a possibility that existing attitudes are formed due to personal experience, mass media and the influence of educational / health institutions. Attitudes are patterns of behavior, tendencies, or anticipatory predisposition readiness to adapt to social or simple situations. Changes that affect the appearance of conditions, fear, doubt, and anxiety can be said to be confusing (Sukardi et al., 2020).

The results of the bivariate analysis between family motivation on the intention / intention of child marriage based on age, gender, father's education and maternal education in Banggai Laut adolescents show that there is an effect of female gender and low maternal education on the intention to carry out child marriage. The results of this study are in line with Johansson's (2015) research in Africa and various countries in the world which shows that girls are at greater risk of child marriage. The results of Sari et al (2019) research show that there is a significant relationship between respondents' attitudes. parents with teenage sexual life style.

The results of the analysis show that there is an effect of behavioral control on the intention to marry children based on age, gender, father's education and mother's education in adolescents in Banggai Laut. The results of this study are in line with the research of Grijns et al (2016) which shows that a lack of behavioral control determines the tendency of child marriage.

Behavior control here is whether it is easy or difficult to marry under the age of marriage. According to the results found, child marriage was very dependent on the ease or difficulty of doing it. One example is that in 2020 there was an underage marriage in Banggai Laut by teenagers who were still in high school with an adult man. The factor of this marriage is not due to pregnancy outside of marriage or due to family encouragement as is often found, but because of the desire of the woman and her partner and family who have let go of the life of the teenage girl, which makes their marriage easier to do. In addition, it is easy to get the headman to get married is the ease of having child marriage and this includes controlling this behavior.

\section{Conclusion}

There is an influence of attitude, family drive and behavior control on the intention / intention to marry children based on age below the mean for Banggai Laut adolescents in 2020. Results of multivariate analysis using multiple logistic regression, namely the Enter method. The analysis showed that there was only one variable that had a $\mathrm{p}$ value $<0.05$, namely the family drive variable with $\mathrm{p}=0.029$. From $\exp (\mathrm{B})=4,871>1$ is a risk factor and the $\mathrm{Cl}$ value is $95 \%$ more than $1(1,178-20,142)$ so that OR is significant. This means that respondents who are influenced by family encouragement have a risk of 4,871 times having the intention of engaging in child marriage. In order to prevent the practice of child marriage, all levels of society should together prevent this from happening, especially in the family environment. The government must pay more attention to strict rules and provide education in the community on the practice of child marriage because the various sources of problems in a country are child marriage because it includes health, education, economic and social problems.

\section{References}

Ajzen, I. \& Fishbein, M. (1980). Understanding Attitudes and Predicting Social Behavior Englewood Cliffs. NJ: Prentice-Hall. 
Ame, K. R. (2013). Overcoming the curse of early marriage in Bangladesh. Asian Journal of Women's Studies, 19(4), 150-163.

Gonzalez-Ricoy, I., \& Rey, F. (2019). Enfranchising the future: Climate justice and the representation of future generations. Wiley Interdisciplinary Reviews: Climate Change, 10(5), e598.

Grijns, M., Sherlywati, S., Agustinah, A., Restuningrum, N. H., Fathurrohman, I. H., Damayanti, V. R., \& Harahap, R. A. (2016). Pernikahan Anak di Sukabumi Jawa Barat: Diri dan Agensi Anak Perempuan (Child Marriage in Sukabumi West Java: Self and Agency of Girls). Jurnal Perempuan: Untuk Pencerahan dan Kesetaraan, 21(1), 9-33.

ICJ. (2019). International Court of Justice. Available from: https://www.icj-cij.org/en

Infodatin. (2015). Pusat Data dan Informasi Kesehatan. Kementerian Kesehatan Republik Indonesia. Available from: https://pusdatin.kemkes.go.id/folder/view/01/structurepublikasi-pusdatin-info-datin.html

Johansson, N. (2015). Child marriage: the underlying reasons and possible solutions. Diva Portal.

Marphatia, A. A., Ambale, G. S., \& Reid, A. M. (2017). Women's marriage age matters for public health: A review of the broader health and social implications in South Asia. Frontiers in public health, 5, 269.

Moedjiono, A. I., Kuntoro, K., \& Notobroto, H. B. (2017). Indicators of Husband's Role in Pregnancy and Maternity Care. International Journal of Public Health Science, 6(2), 192-196.

Moedjiono, A. I., Mallongi, A., \& Tamar, M. (2020). Determinant of unmeet need family planning in Indonesia (PMA 2015). Enfermeria clinica, 30, 379-382.

Rifai, N.A., Moedjiono, A.I., Abdullah, M.T., Russeng, S.S., Seweng, A., Hidayanti, H., (2019). The Influence of Maternal Age, Pregnancy Stress, Nutrition Status and Utilization of Anc against the Incidence of Low Birth Weight Infant In Public Hospital Public, Bantaeng Regency. EAS Journal of Nursing and Midwifery, 1(4).

Sari, U.H.P., Moedjiono, A.I., Bustan, M.N., (2019). Determinants of Premarital Sexual Behavior of Young Men in Indonesia (IDHS Data Analysis 2017. East African Scholars Journal of Education, Humanities and Literature, 11(2).

Sukardi, T.A., Moedjiono, A.I., Seweng, A., Masni, Tamar, M., (2020). The Effect Reproductive Health Education Toward Attitude of Cancer Services in High School Students in West Part Seram Regency. European Journal and Reflection in Educational Sciences, 8(7).

Parsons, J., Edmeades, J., Kes, A., Petroni, S., Sexton, M., \& Wodon, Q. (2015). Economic impacts of child marriage: a review of the literature. The Review of Faith \& International Affairs, 13(3), 12-22. 